\title{
Efforts to Improve Activeness and Learning Outcomes of Integrated Social Sciences Through Time Token Type Cooperative Learning Model
}

\author{
Agus Herianto $^{1}{ }^{*}$, Nurjannah $^{2}$, Mahsup $^{3}$, Sintayana Muhardini $^{4}$, Ibrahim $^{5}$, Eka Fitriani ${ }^{6}$ \\ ${ }^{1 *}{ }^{*}$ Program Studi Pendidikan Geografi, ${ }^{3}$ Program Studi Pendidikan Matematika, \\ ${ }^{4}$ Program Studi PGSD, ${ }^{2}$ Program Studi Pendidikan Bahasa Arab, \\ FKIP, Universitas Muhammadiyah Mataram \\ ${ }^{6}$ TK IT Abata Lombok \\ *Corresponding Author. Email: agusherianto.ummat@gmail.com
}

\begin{abstract}
This research aims to improve the activeness and results of integrated IPS learning by implementing a cooperative learning model of Time Token type (TITO). This type of research is class action research with the subject of the study is grade VII students MTs Nurul Masak in school year 2019/2020. Research was carried out in three cycles, each cycle was carried out with 2 actions and consisted of 4 stages namely planning, implementation, observation, and reflection. The population and samples in the study were grade VII students of MTs Nurul Masakin. The research instruments used in the implementation of this action research were observations, interviews, and field notes as well as tests of students' learning outcomes on each cycle. This study used two forms of data analysis, namely quantitative analysis and qualitative analysis. Quantitative data were obtained from the percentage of students' activities in participating during the learning process and student learning results and qualitative data were used to describe data in the form of numbers in order to provide a clear picture of the activities and learning results that had been done. Based on the results of the study it showed that there was an improvement in Integrated Social Science learning outcomes using the Method of Cooperative Learning Type Time Token (TITO) which was the average value gain that each cycle increased. In Cycle I the average value obtained was 6.5 , while in cycle II the average gain value reached 7.40 and in cycle III, the average value reached 8.18 .
\end{abstract}

\section{Article History}

Received: $16-05-2020$

Revised: 02-10-2020

Accepted: 06-03-2021

Published: 07-09-2021

\section{Key Words:}

Activeness, Learning Outcomes, Integrated IPS, Time Token Cooperatives.

How to Cite: Herianto, A., Nurjannah, N., Mahsup, M., Muhardini, S., Ibrahim, I., \& Fitriani, E. (2021). Efforts to Improve Activeness and Learning Outcomes of Integrated Social Sciences Through Time Token Type Cooperative Learning Model. Jurnal Kependidikan: Jurnal Hasil Penelitian dan Kajian Kepustakaan di Bidang Pendidikan, Pengajaran dan Pembelajaran, 7(3), 719-728. doi:https://doi.org/10.33394/jk.v7i3.2626

dC. https://doi.org/10.33394/jk.v7i3.2626

This is an open-access article under the CC-BY-SA License.

\section{Introduction}

Education is a very influential field to improve the quality of human resources. Education develops along with the development of Science, Technology, and Art (Arta Diantoro, Mahsup, \& Pramita, 2019). Everything related to education must be able to adjust to the development of science and technology. (Sintayana Muhardini, Sukron Fujiaturrahman, 2018). This happens because in the 21st-century people are said to excel when they are educated and master science and technology. Better education is expected to produce better human resources. Therefore, the combination of technology and education plays a role to form capable, creative, skilled, and professional human resources (Mandailina \& Mahsup, 2018).

To support the successful implementation of education, it is necessary to provide an environment that allows learners to develop talents and abilities optimally (Suharsimi; 2013). Learners can realize themselves and function fully, following their personal needs and the needs of the community following the national education objectives stated in the National 
Education System article 3 which reads to develop the potential of learners to become human beings who are noble, healthy, knowledgeable, capable, creative, independent, and become democratic citizens and responsible and functioning to develop the ability and shape the character and civilization of a useful nation to educate the life of the nation (UU RI, 2003). So that a teacher must be able to carry out his function as a learning agent who acts as a facilitator, booster, learning engineer, and learning inspiration for learners (Ratnawati, 2016)

Learning is an important human activity and can not be separated from human life, from birth to the end of human life is never separated from the learning process (Arikunto, 2008). Starting from the family environment, community, and human school is always required to continue learning. A school is a place that is most closely related to learning activities (Mahsup \& Abdillah, 2019)(Fitriani \& Mahsup, 2018). If the process and results are good, then it can be said that the quality of learning is also good (Herianto, Ali, Arif, \& Khosiah, 2019). The success of learning can be influenced by the learning model used by the teacher. If the learning model is interesting and centered on students (student-centered learning) then the motivation and attention of students will increase and then the quality of learning can also improve (Herianto \& Ibrahim, 2017) (Mukminah et al., 2020)

Interest in learning is an important thing to note in achieving the quality of learning and student learning outcomes (Mahsup, 2018). Efforts to increase student learning interest are closely related to the implementation of learning. The method is one of the components in learning that is under the control of the teacher, meaning that the teacher has full authority to direct and choose the right method to achieve the learning objectives because the method that is not appropriate will make the learning such as coercion, monotony, and material is not conveyed properly, directing the learner to do the learning activities themselves requires help from the teacher who serves as a facilitator in the learning process. This assistance is needed for all learning processes, as well as in the learning of Integrated Social Sciences (Herianto \& Ali, 2020)(Mahsup \& Anwar, 2020).

Regulation of the Minister of National Education No. 22 of 2006 concerning Content Standards of Elementary and Secondary Education Units containing Competency Standards (SK) and Basic Competencies (KD) of Social Sciences (IPS) at the junior high school level, covering geography, history, economics, and sociology materials. Its subjects are organized systematically, comprehensively, and integrated, with integrated learning is expected to be more meaningful for students in the context of daily life. Students will gain a fuller and broader understanding. In standard content of junior high school social sciences subjects have not been fully integrated, so it becomes a burden and not infrequently cause confusion for teachers because there is a continuity between the purpose and objectives of social sciences and the implementation in the field. Therefore, efforts are needed with the development of study materials that exist in the standard content into themes that are taught in an integrated manner. In reality, there are still many teachers who have difficulty to carry out learning in an integrated manner.

Whereas in integrated IPS competence is not the only History, there is Sociology, Anthropology, and Geography. In the delivery of integrated IPS competencies, there are obstacles or obstacles faced either from the teacher or learners. For example, teachers have not mastered the competencies to be taught, there is no support for learning media, students are not ready to receive lessons, and methods of teaching teachers are monotonous. Based on the observations of IPS learning in Grade VII MTs Nurul Masakin there were similar constraints, in which IPS material was taught separately. Another obstacle was that, the learning was carried out monotonously through lecture methods which made students less enthusiastic in following the learning so that students rarely asked questions about lessons 
that were still not understood and students only listened to teachers delivering the learning materials. Students' learning outcomes were still also only at the lowest level, i.e. at the remembering level only because students only memorized what was recorded from the teacher and that was in the package book. This contradicts the following statement: "Learning is not just a memorization activity, many memorable things will be lost in a few hours. Learning is not swallowing everything. Students must process and understand the subject matter to remember what their teacher has taught. A teacher also cannot immediately pour something into the minds of his students, because it is they who must organize what they hear, see, into a meaningful unity. The learning process needs to be done in waves, proximity to the material studied, long before learning it (Costley, 2009).

Nowadays IPS teachers in MTs Nurul Masakin Karang Lebah still use conventional teacher-oriented learning models, in which in the process of teaching and learning teachers more often use monotonous teaching methods, by lecture methods, and question and answer. This will certainly cause saturation for students in teaching and learning activities. The method becomes less good to be used in understanding integrated IPS competencies. Therefore, classroom learning is not only centered on teachers and textbooks but must pay attention to how students can understand the material delivered. In learning students at MTs Nurul Masakin also tend to be passive and difficult to be invited to be more active, creative, and confident. For example, students have not dared to ask if they do not understand, and at the time of class discussion, many are silent and do not express their opinions, so that learning in the classroom is less effective and conducive. If the teacher explains continuously, the students feel bored and then talk to their classmates and play alone.

This makes students' learning outcomes low because as many as $75 \%$ of students have not met the KKM (70) score. Another case encountered during observation is that the integrated IPS lesson hours take place during the day and are considered less optimal. Students feel bored and tired quickly causing the noise. The above problems require the right solution for the learning target to be achieved. One of the steps that will be taken is to use a Time Token type cooperative learning model. Cooperative Learning method with Time Token type aims so that students not only watch the teacher who is talking in front of the class, but students also play an active role in the learning process. This method is expected to encourage the success of students to understand the subject matter taught by the teacher. One of the things that can increase students' learning interest is by applying learning methods that require the active participation of students, as mentioned above, the Cooperative Learning method with time token techniques.

Through Time Token type cooperative learning model, students are required to be able to more actively express their opinions in learning and be able to listen to the opinions of others. The advantage of the Time Token method is that all students actively give opinions in learning activities and can foster students' courage in expressing opinions for students who are shy and difficult to talk to. Time Token learning emphasizes the activities and interactions between students to help each other master the subject matter in order to achieve maximum results. Based on the description above, this research aims to improve the students' activeness and learning outcomes of integrated IPS learning by implementing a cooperative learning model of Time Token type (TITO).

\section{Research Method}

The research method used is classroom action research (CAR) using Kemmis and Taggart models. The Kemmis and Taggart models are a development of the basic concept introduced by Kurt Lewin, only that the acting and observing components are united because 
they are inseparable actions, occurring at the same time. In its planning, Kemmis \& Taggart uses a spiral system of self-reflection that begins with planning, acting, observing, reflecting, and re-planning which is the basis for solving problems. The archaic model of PTK according to Kemmis and Taggart is shown in figure 1 below:
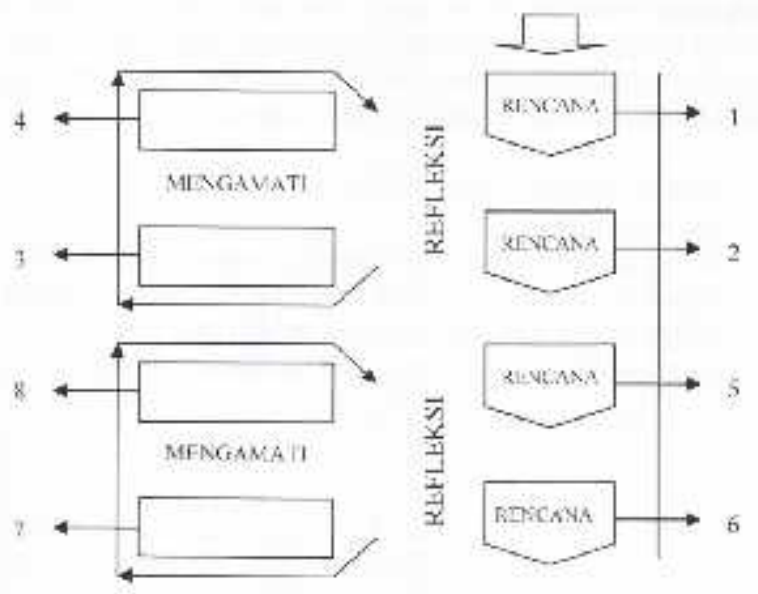

- Planning

\section{Figure 1. CAR Model Spiral Kemmis and Taggart}

At this stage, it is necessary to plan carefully after the researchers know the problems in learning experienced by the teacher. At this planning stage, researchers plan the actions that will be done in the learning process.

- Implementation

The implementation of action is a teaching and learning activity that can be carried out in several meetings in each cycle. In this research there are several stages of activities in the learning process, which are: (1) Initial activity stages; (2) Core activities (presentation of materials), and (3) Closing activities.

- Observations

Each action implementation is inseparable from observation as part of the implementation of action research.

- Reflection

This reflection is based on the notes and observations that have been made by teachers and researchers. Researchers along with teachers and observers then discussed the resulting impact and compared it to the circumstances before being given action.

The population used are students of MTs Nurul Masakin class. Students consist of

grade VII. Research objects that are still in the form of populations should be reduced to a sample of research. By using purposive sampling, samples are determined based on certain criteria or considerations so as not to go through the selection process as done in random techniques. The sample in this study was grade VII MTs student Nurul Masakin from a predetermined population as a sample to be studied. The research instruments used in the implementation of this action research are observations, interviews, and field notes as well as tests of students' learning outcomes in each cycle.

To analyze the data of student learning activities observed used percentage technique $(\%)$, ie the number frequency of each activity divided by all activities multiplied by 100 .

Percentage of Student Responses $=\frac{A}{B} \times 100 \%$

Where:

$A=$ The proportion of students who voted

$\mathrm{B}=$ the number of students (Respondents) 
To determine the student's learning ability is used test instruments that include products, processes, and psychomotor. Determination of completeness based on the assessment of benchmark reference. Analysis of the test results of learning is by calculating the average value in each cycle is to use a formula $M=\frac{\sum F_{x}}{N}$

\section{Finding and Discussion}

\section{Cycle I}

Before conducting the research, researchers first prepare the following to analyze the curriculum to find out the Core Competencies (KI) and Basic Competencies (KD), make a lesson implementation plan (RPP), prepare to teach materials, tools and materials, and are ready to facilitate students in the learning process and prepare observation sheets for both teachers and students. The teacher opened the lesson by saying hello, doing a brief review, and conveying the KD that will be achieved, namely understanding the concept of space and interaction between spaces in Indonesia and its influence on human life in economic, social, cultural, and educational aspects. Before the teacher delivers the learning material, the teacher first explains the learning method that will be applied, then conveys the procedures for students to conduct the learning following the steps of the Time Token type cooperative learning model (TITO). During the activity, there was direct observation of students' activities in integrated social science learning. At this first meeting, the number of incoming students was 25 students (100\%) 25 students.

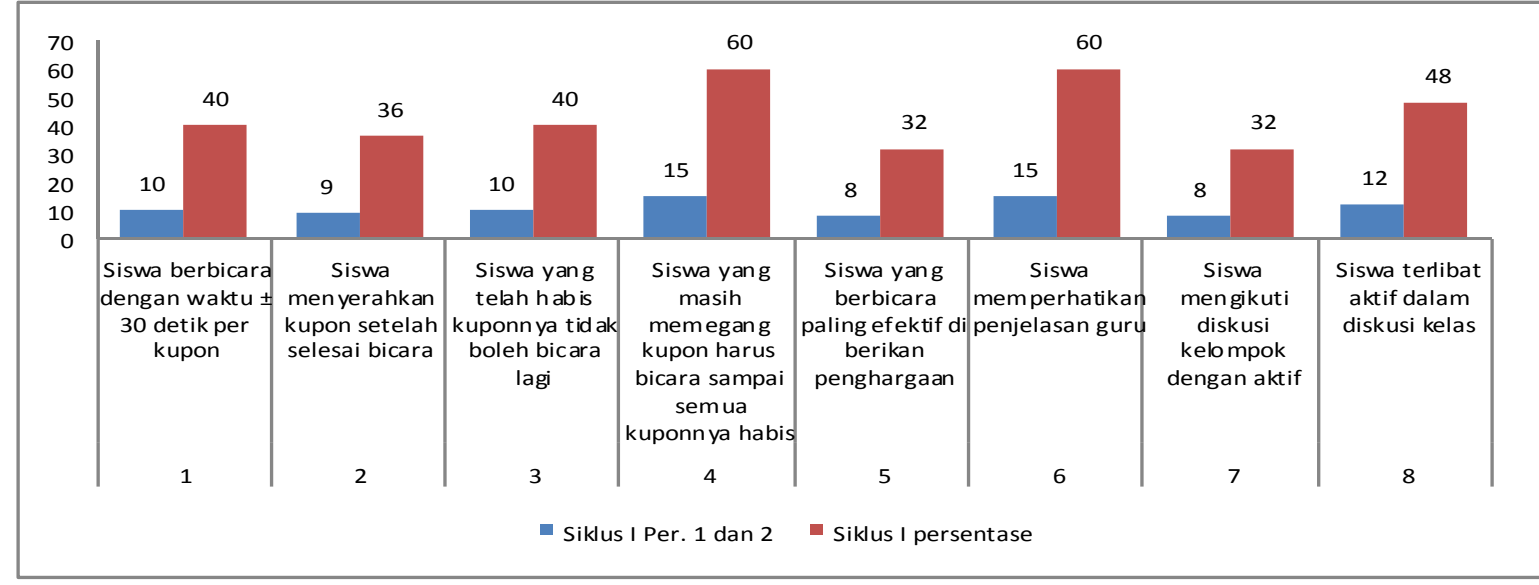

Gambar 2. Graph of Student Activities in Cycle I Meetings 1 and 2 Tabel 1. Skor Tes Siklus I

\begin{tabular}{cccc}
\hline Skor & F & \% & fx \\
\hline 8 & 2 & 8 & 16 \\
7 & 8 & 32 & 56 \\
6 & 7 & 28 & 42 \\
5 & 8 & 32 & 40 \\
Jumlah & 25 & 100 & 154
\end{tabular}

The calculation of average values in cycle I is as follows:
$M=\frac{\sum F_{x}}{N}$
$M=\frac{154}{25}=6,16$ 


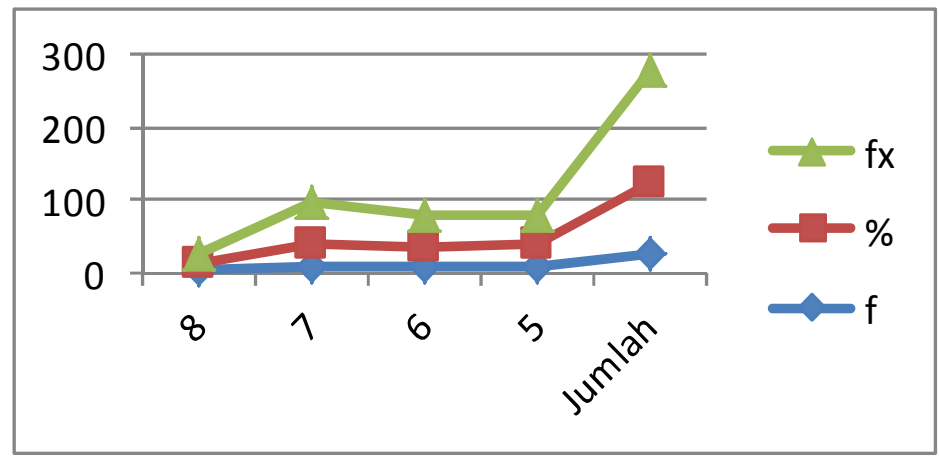

Figure 3. Cycle I Test Score Graphic

Learning in the first cycle is carried out so that students can understand the geographical conditions of Indonesia, the potential of SDA and HR by applying a cooperative learning model type Time Token (TITO). The first cycle has not been implemented optimally, because students are not familiar with this learning model, so the expected activities are not yet maximal. The average value of cycle I am 6.16 and the pretest is 6.00 .

\section{Cycle II}

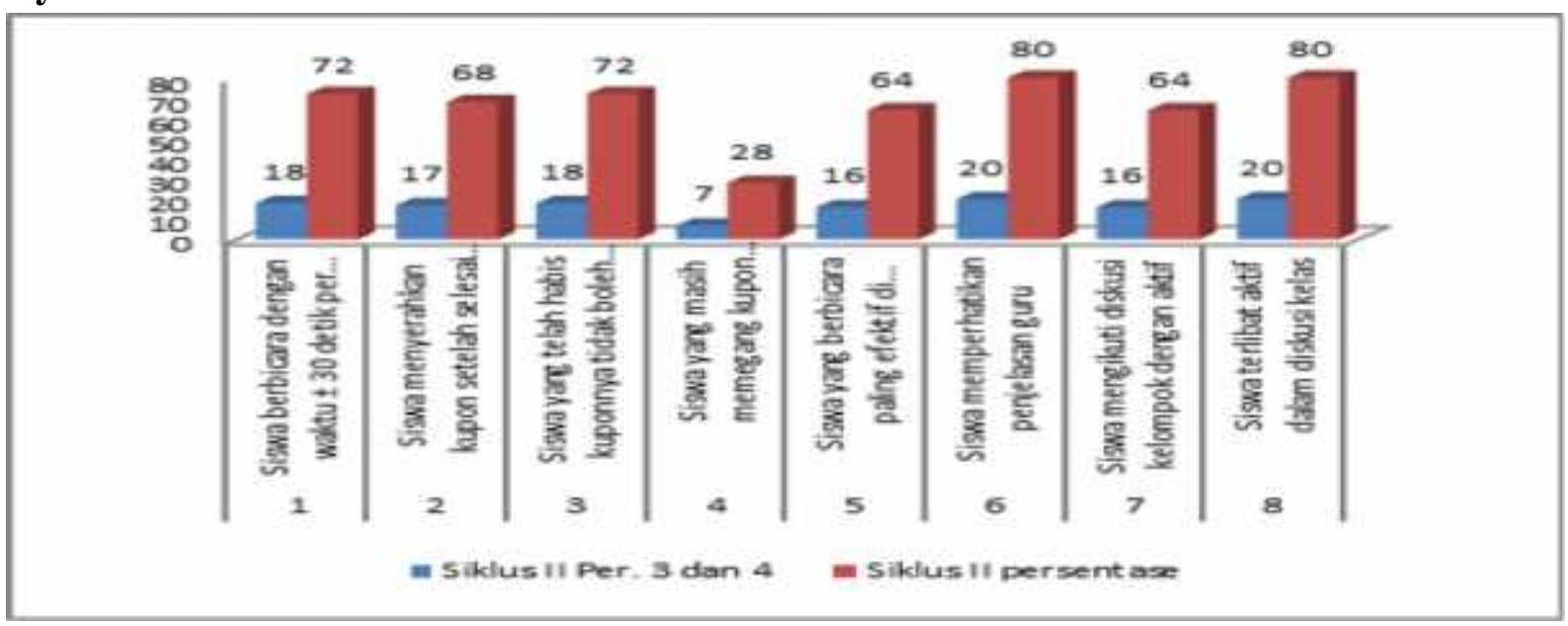

Figure 4. Graph of Student Activity in The Second Cycle of Meetings 3 and 4

The planning carried out in the second cycle is a continuation of the KD in the first cycle with the material presenting the results of studying the concept of space and interaction between Indonesian spaces and their influence on the lives of Indonesian people in economic, social, cultural and educational aspects. The teacher opens the lesson by saying hello, doing a brief review, and conveying the KD that will be achieved. As in the previous meeting, the teacher still conveyed the procedures for students to conduct learning activities following the steps of the Time Token type cooperative learning model (TITO). During the activity, there was direct observation of students' activities in integrated social science learning. At the third meeting, the number of incoming students was 25 students (100\%). Student activity in this cycle has made progress. Students are already active in learning.

Table 2. Test Scores On Cycle II

\begin{tabular}{cccc}
\hline Shoes & F & \% & fx \\
\hline 8 & 7 & 28 & 56 \\
7 & 17 & 68 & 119 \\
6 & 1 & 4 & 6 \\
Amount & 25 & 100 & 181
\end{tabular}

Jurnal Kependidikan Vol. 7, No. 3 : September 2021 
The calculation of average values in cycle II is as follows:

$$
M=\frac{\sum F x}{N} \quad M=\frac{181}{25}=7,24
$$

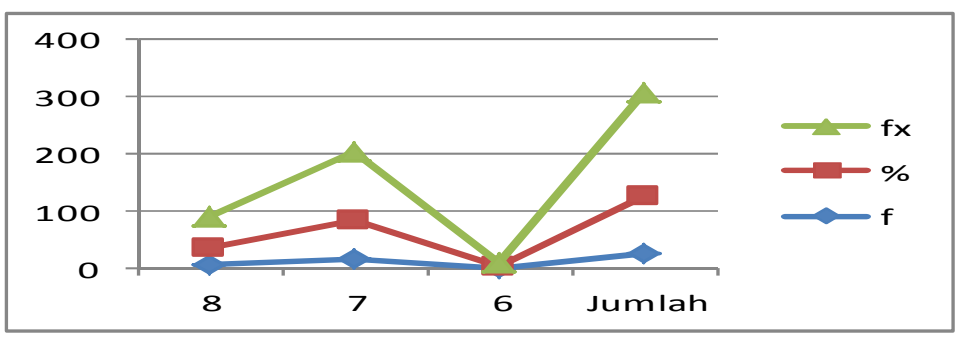

Figure 5. Cycle Ii Test Score Graph

Thus, the average score of the second cycle test score increases when compared to the average test score in cycle I. In this cycle the teacher has carried out the learning in accordance with the established plan. The implementation of the Time Token (TITO) cooperative learning model in the second cycle has progressed, students have been more active than in the first cycle. The average gain in cycle II is 7.24. That means that the average value of cycle II increases compared to the first cycle with an average value of 6.57 .

\section{Cycle III}

In cycle III researchers first, make preparations made based on inputs from the results of cycle II reflections. The learning system in cycle III contains learning activities that of course use a Time Token (TITO) type cooperative learning model. In this third cycle, KD is analyzing social interactions in space and their influence on social, economic, and cultural life in values and norms and socio-cultural institutions. The teacher opens the lesson by saying hello, doing a brief review, and conveying the KD that will be achieved. As in the previous meeting, the teacher still conveyed the procedures for students to conduct learning activities using a Time Token (TITO) type cooperative learning model. This is done to avoid students who do not understand the application of the learning model. During the activity, there was direct observation of students' activities in integrated social science learning. In this cycle, the number of incoming students is 25 students (100\%). Student activity at this meeting has increased a lot.

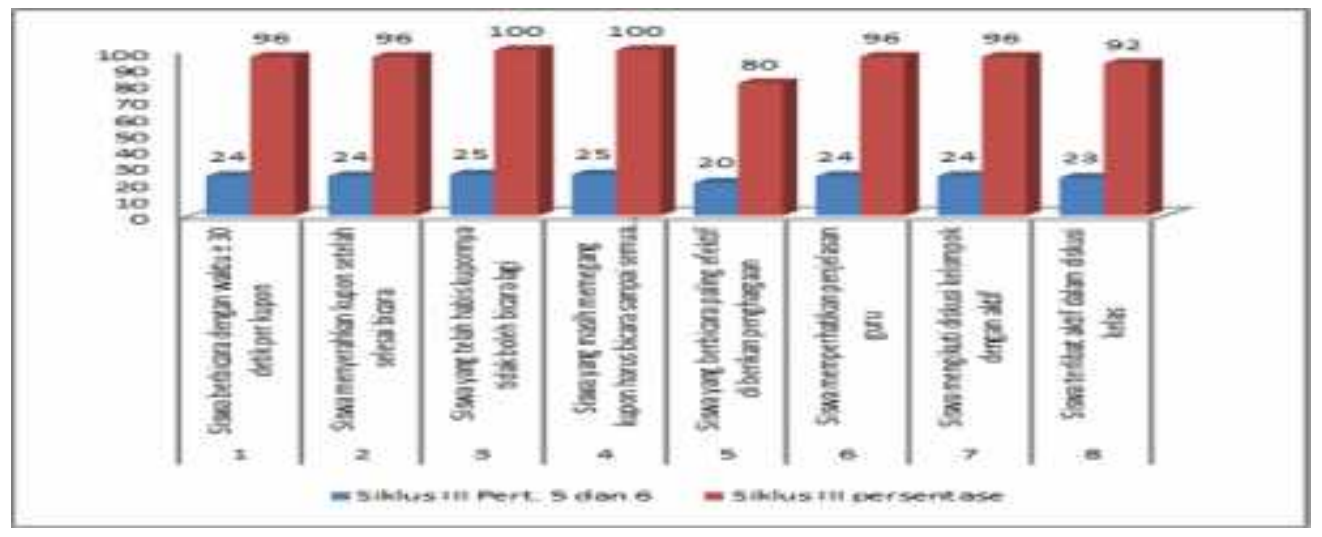

Figure 6. Graph of Student Activity In The Third Cycle of Meetings 5 and 6 Table 3. Test Scores On Cycle III

\begin{tabular}{cccc}
\hline Shoes & F & \% & fx \\
\hline 9 & 3 & 12 & 27
\end{tabular}




$\begin{array}{cccc}8 & 17 & 68 & 136 \\ 7 & 5 & 20 & 35 \\ \text { Amount } & 25 & 100 & 198\end{array}$

The calculation of average values in cycle III is as follows:

$$
M=\frac{\sum F_{x}}{N} \quad M=\frac{198}{25}=7,92
$$

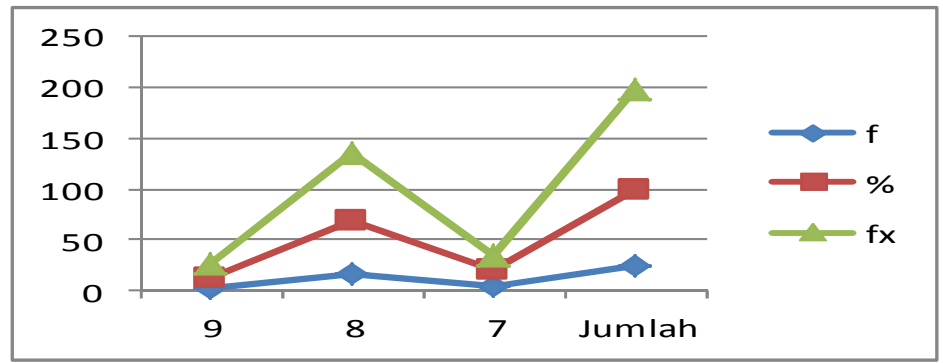

Figure 7. Cycle III Test Score Graph

Thus, the average score of cycle III test scores increases when compared to the average score of cycle II test scores. In this cycle, teachers have tried to carry out learning following the established design. Teachers have been able to create a conducive learning atmosphere. Also, in the third cycle, teachers are involved in attracting students to take lessons compared to the previous cycle. This can be seen from the activities of students who are getting better from each meeting. Learning in the third cycle is focused so that students can understand the material of social interaction, the influence of social interaction, and social institutions. The activities of students and teachers in this third cycle have shown significant progress. In this third cycle, students become more active in the group, trying to research and analyze data, as well as solving problems. Student cooperation has also improved a lot. The average value in cycle III is 7.92. That means that the average value of cycle III has increased compared to the second cycle where the average value is 7.24.

The results of the study were obtained that a time token type cooperative learning model (TITO) can create an interesting learning atmosphere that involves students as a whole in the learning process and can improve students' speaking skills. In research (Sahara, 2020) concluded that there is a significant influence of the time token type cooperative learning model on the speaking skills of grade V students at SDN Cluster IV in Turi Subdistrict, Lamongan Regency. Also, time token type cooperative learning model (TITO) can improve students' learning activities. The results of the study (Githa, Sugiarta, \& Puja Astawa, 2019) showed that the cooperative learning model of time type together affects students' communication skills and learning activities $(\mathrm{F}=22,276 ; \mathrm{p}<0.05)$; positively affect students' math communication skills $(\mathrm{F}=34,726 ; \mathrm{p}<0.05)$; and student learning activities $(\mathrm{F}=12,257$; $\mathrm{p}<0.05)$.

\section{Conclusion}

Based on the research that has been done, it can be concluded that efforts to improve the students' activeness and learning outcomes of integrated IPS in MTs Nurul Masakin Karang Lebah can be determined by using a cooperative learning model type Time Token (TITO) and combine it with lecture and question and answer methods. The evidence that shows the improvement of IPS learning results by using the Time Token Type Cooperative Learning method is the average value gain that each cycle increases. Cycle I the average value obtained by 6.5 in the second cycle increased by 7.40 and increased again in the third cycle, obtaining an average value of 8.18 . 


\section{Suggestion}

In using The Time Token Type Cooperative learning method to improve student learning outcomes, teachers should take steps that are clear problems to solve, find data or information that can be used to solve the problem, establish temporary answers to the problem, test the correctness of the temporary answer and draw conclusions. We recommend that The Time Token Type Cooperative learning method can be applied by geography IPS teachers and another field of study teachers as an alternative to improving student activity and learning achievement. Also, it is necessary to further research on the application of learning methods following the subjects and subject matter where the method can produce maximum academic achievement.

\section{References}

Arikunto, S. (2008). Evaluation of Education Program. PT Bumi Aksara, 227. https://doi.org/10.1109/TEVC.2004.826389

Arta Diantoro, S.B., Mahsup, M., \& Pramita, D. (2019). Implementation of Cooperative Learning Model Type Two Stays Two Stray (TSTS) In Improving Learning Outcomes Form Algebra Of Grade VII Junior High School Students. Paedagoria | FKIP UMMat, 10(1), 01. https://doi.org/10.31764/paedagoria.v10i1.811

Costley, K.C. (2009). Charles Silberman's "Crisis in the Classroom, The Remaking of American Education": A Critical Analysis. Online Submission.

Fitriani, E., \& Mahsup, M. (2018). The Effect of Jigsaw Type Cooperative Learning To Improve Understanding. Justek : Journal of Science And Technology. https://doi.org/10.31764/justek.v1i2.3541

Githa, P. S., Sugiarta, I.M., \& Puja Astawa, I. W. (2019). The Influence of Time Token Type Cooperative Learning Model on Communication Ability And Learning Activities of Grade VIII Students of SMP Negeri 2 Singaraja. Journal of Mathematics Education Undiksha, 10(2), 78. https://doi.org/10.23887/jipm.v10i2.19933

Herianto, A., \& Ali, I. (2020). Development of Constructivist Based Environmental Geography Teaching Materials With Cooperative Learning Model. Journal Of Geography, 12(01), 307. https://doi.org/10.24114/jg.v12i01.10688

Herianto, A., Ali, I., Arif, A., \& Khosiah, K. (2019). Class Action Research Writing Training for MTs And MI Darul Masakin Teachers in Bilelando Village, Central Lombok. JMM (Independent Society Journal), 3(1), 58. https://doi.org/10.31764/jmm.v3i1.922

Herianto, A., \& Ibrahim, I. (2017). Analysis of the effectiveness, advantages, and disadvantages of cooperative learning model design in improving the motivation and results of learning environmental geography in students of geography education study program on the island of Lombok. Proceedings of the National Seminar of Indonesian Education Educators and Developers with the theme "Building Character Generation Through Innovative Learning". Handayani Hall IKIP Mataram October 14, 2017, $17-$ 27.

Mahsup, \& Abdillah, A. (2019). Application of Learning Discussion Methods To Improve Student Math Learning Outcomes On Determinant Materials. Jurnal Ulul Albab, 23(1), 33. https://doi.org/10.31764/jua.v23i1.643

Mahsup, M. (2018). Analysis of Difficulties In Understanding Verbal Ability In Creating Linear Program Mathematical Models. Ulul Albab Journal, 22(2). https://doi.org/10.31764/jua.v22i2.594

Mahsup, \& Anwar, Y. S. (2020). Development of structured modules to improve the mathematical understanding of the circle concept in class VIII Mataram 17 junior 
high school. Journal of Physics: Conference Series, 1465(1). https://doi.org/10.1088/1742-6596/1465/1/012074

Mandailina, V., \& Mahsup. (2018). Effectiveness of Mathematics Learning with Thinking Aloud Pair Problem Solving (TAPPS) Method on Learning Outcomes of Students of Cube And Block Class VIII SMP/MTs. Journal of Theory and Application of Mathematics (JTAM), 2(2), 144-147.

Mukminah, M., Fitriani, E., Mahsup, M., \& Syaharuddin, S. (2020). Effectiveness of Team Games Tournament Type Cooperative Learning Model To Improve Learning Outcomes. Justek : Journal of Science And Technology. https://doi.org/10.31764/justek.v2i2.3533

Ratnawati, E. (2016). The Importance of Integrated Social Science Learning. Journal Article, 15.

Sahara, I. (2020). The Influence of Time Token Type Cooperative Learning Model on The Speaking Skills of Grade V Students at SDN Cluster IV Kec. Turi .... Journal of Teacher Education Research...

Sintayana Muhardini, Sukron Fujiaturrahman, M. (2018). Development of Thematic Learning Media SD Based Bulletin Board Display. Proceedings of the National Seminar on Indonesian Education Educators and Developers, 285-291

Suharsimi;, A. (2013). Education Evaluation Basics. In Jakarta: Bumi Aksara.

Ri Law. Law No. 20 of 2003 on the National Education System in Article., Ministry of National Education § (2003). 